\title{
TRYPANOSOMA (HERPETOSOMA) RANGELI TEJERA, 1920. INTRACELLULAR AMASTIGOTE STAGES OF REPRODUCTION IN WHITE MICE
}

\author{
Servio URDANETA-MORALES \& Felix TEJERO
}

\section{S U M M A R Y}

The method, site, and stage of multiplication of Trypanosoma (Herpetosoma) rangeli Tejera, 1920 has not hitherto been known. We have now observed many intracellular nests or pseudocysts, containing amastigotes and trypomastigotes of this parasite in the heart, liver, and spleen of suckling $(5.0 \mathrm{~g})$ male white mice (NMRI strain) inoculated i.p. with $9 \times 10^{4}$ metatrypomastigotes/g body weight from a 12-day-old culture of the "Dog-82" strain of $\mathbf{T}$. rangeli. At the peak of parasitemia (1.9 $\times 10^{6}$ trypomastigotes $/ \mathrm{ml}$ blood, 3 days post-inoculation) various tissues were taken for sectioning and staining. The heart was most intensely parasitized. The amastigotes were rounded or ellipsoidal, with a rounded nucleus and the kinetoplast in the form of a straight or curved bar; the average maximum diameter of 50 measured amastigotes was $4.2 \mu$. Binary fission 'was seen in the nucleus and kinetoplast of some amastigotes; no blood trypomastigotes were seen in division. The above characteristics, as well as the location of the pseudocysts in the tissues, are similar to T. cruzi. Comparison of these results with those reported for other Herpetosoma suggest study of the taxonomic position of $\mathbf{T}$. rangeli.

KEY WORDS: Trypanosoma (Herpetosoma) rangeli: Experimental infection white mice. Intracellular amastigote stages of reproduction heart - liver - spleen

\section{N T R O D U C T I O N}

Since its discovery by TEJERA 15 , many fruitless attempts have been made to find the site and reproductive mechanism of Trypanosoma (Herpetosoma) rangeli Tejera, 1920 in mammals (HOARE'). Our use of a mouse model (URDANETA-MORALES \& TEJERO ${ }^{17}$ ) for obtaining high parasitemias has enabled us to find intracellular amastigotes multiplying in various organs.

\section{MATERIALS AND METHODS}

The details of the "Dog-82" strain of Trvnanosoma rangeli used have already been describ. ed (URDANETA-MORALES \& TEJERO ${ }^{17}$ ). The strain has been clearly distinguished from $\mathbf{T}$. cruzi by: morphology, locomotor movements, course of parasitemia, invasion of the hemolymph and salivary glands of triatomids, and lack of ability of the parasites to confer immunity against subsequent infection by $T$. cruzi. On the other hand, a biochemical characterization of the "Dog-82" strain was carried out using a detailed comparison of the molecular and kinetic properties of the neuraminidase present in the parasite surface and released to the culture medium. The molecular weight, substrate specificity, and specific activity of the

Instituto de Zoologia Tropical. Facultad de Ciencias Universidad Central de Venezuela. Apartado 47058 - Caracas 1041-A. Venezuela. 
URDANETA-MORALES, S. \& TEJERO, F. - Typanosoma (Herpetosoma) rangell TEJERA, 1920. Intracellular amastigote stsges of reproduction in white mice. Rev. Inst. Med. trop. 8650 Paulo, 28:166-169, 1886.

"Dog-82" strain enzyme was identical to that of 2 bona-fide $T$. rangeli strains and differed completely from that present in cloned and unclon. ed $\mathbf{T}$. cruzi strains maintained in our laboratory (URBINA, personal communication ${ }^{2}$ ). Furthermore, mice were inoculated i.p. with the " $\mathrm{Y}$ " strain of $\mathbf{T}$. cruzi in blood from mice in which the strain had been maintained. On Day 7, when the parasitemia of $\mathbf{T}$. cruzi had reached its peak, the same mice were inoculated i.p. with T. rangeli from culture. Blood smears taken 2 days later showed clearly distinguishable trypomastigote forms of both $\mathbf{T}$. cruzi and $\mathbf{T}$, rangeli.

Eight $5.0 \mathrm{~g}$ suckling male mice (NMRI strain) were inoculated i.p. with $1.5 \times 10^{6} \mathrm{fla}$ gellates/g body weight from a 12-day-old culture in LIT medium. Six percent of the flagellates were metatrypomastigotes, thus each mouse was inoculated with $9 \times 10^{4}$ metacyclic forms/ g body weight. Parasitemia was checked after $24 \mathrm{hr}$ and thenceforth daily as already described. Two mice were killed by cervical dislocation at the peak of parasitemia on the third day and the heart, liver, spleen, lungs, femoral bone marrow, muscle, cartilage, sternal bone marrow, and kidneys were taken to be fixed in $10 \%$ formol, imbedded in paraffin, and cut into 5 A serial longitudinal sections which were stained with hematoxylin-eosin. Microphotographs were taken as already described. The greatest diameters of the intracellular amastigotes were measured in 50 examples with an ocular micrometer under oil immersion (1000 X).

\section{RESULTS}

Parasitemias of $1.8 \times 10^{6}$ trypomastigotes/ $\mathrm{ml}$ blood were observed as early as $24 \mathrm{hr}$ post. inoculation (Fig. 1), being maintained up to the third day, when the organs were taken. No blood flagellates were seen to be in division. Nests or pseudocysts of intracellular amastigotes and trypomastigotes (Figs. 2-8) were seen in the heart, liver, and spleen sections. The heart was noticeably more intensely parasitized in a disseminated fashion The average maximum diameter of the $\mathbf{5 0}$ measured amastigotes was $4.2 \mu$. They were ovoid, ellipsoid, or rounded. with a large rounded nucleus, and the kinetoplast appearing in the form of a straight or curved bar. Several amastigotes were seen with nuclei and kinetoplasts in bina- ry fission. The other six experimental animals developed chronic infections and did not die.

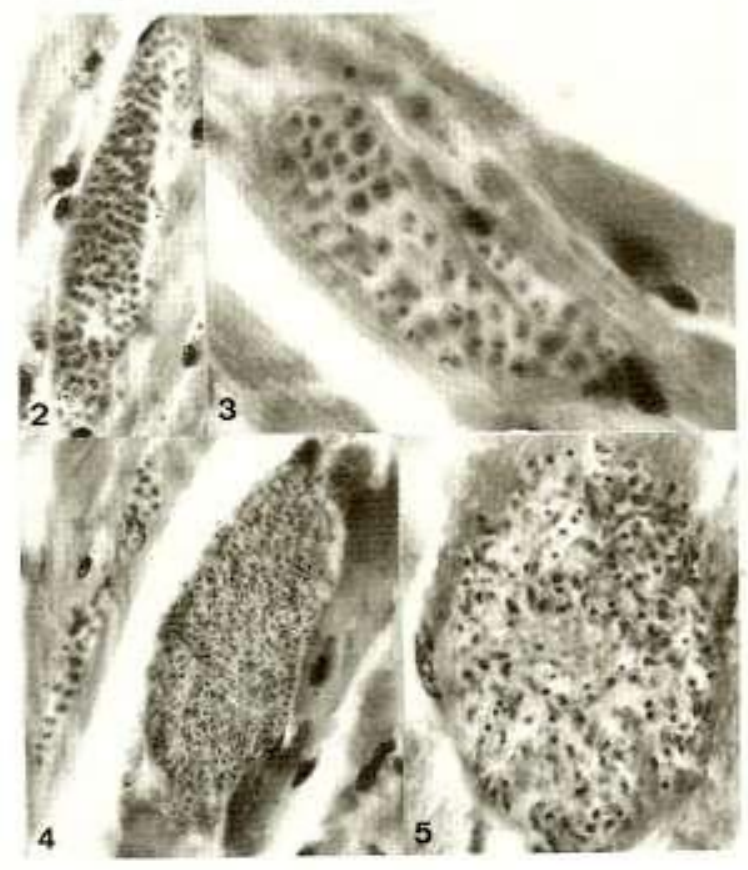

Fig. 1 - Parasiternias of rnuce expertmentally infocted with Trypanosoma rangell

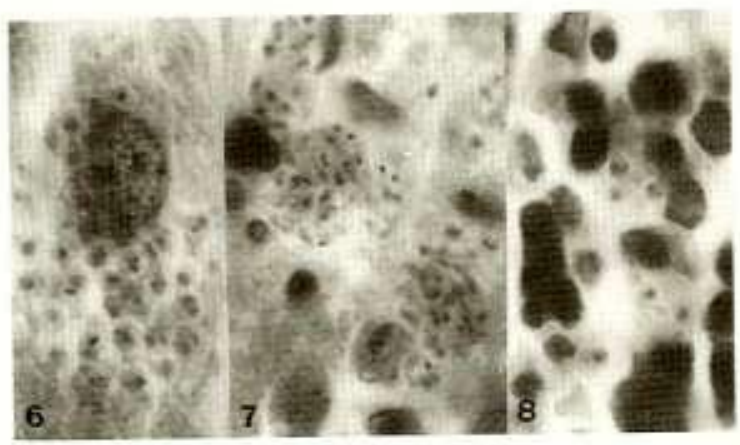

Pig. 2-8 - Intracellular stages of $\mathbf{T}$. rangell in organs rrom experimentally infected mice:

$2-3$ - Nests of amastigotes in cardiac muscle $(750 \mathrm{x}$. 1400 X): 4-5 - Pseudocysts of trypomastigotes in heart (750 X, $1400 \mathrm{X}$ ).

6 - Pseudocysts of amastigotes in hepatic paranchyms cell $(1300 \mathrm{X}) ; 7$ - Nests of trypomastigotes in liver $(1300 \mathrm{X}) ; 8$ - Amastigotes in spleen tissue $(950 \mathrm{X})$

\section{DISCUSSION}

T. rangeli causes trypanosomiases in man and in other mammals in the Neotropical region (PIFANO ${ }^{13}$ ). In 1936, De Leon (PIFANO ${ }^{13}$ ) described the first human cases, reporting blood forms in division (ZELEDON ${ }^{19}$ ) and suggest- 
ing this as the normal mode of reproduction in the vertebrate host. However, most workers have not found dividing forms in blood (PIFANO ${ }^{13}$; D'ALESSANDRO ${ }^{3}$; ANEZ ${ }^{1}$ ) nor in tissues (HERBIG-SANDREUTER 7; PIFANO 14) although blood trypomastigotes in a predivision stage have been observed by GREWAL 5 and TOBIE 16. MOLYNEUX 11, studying T. rangeli infections of mammalian cell cultures at $37 \mathrm{C}$, deduced that the parasite probably multiplied extracellularly by binary fission of trypomastigotes in the mammal. Forms in division found in certain viscera of experimental hosts by DEA$\mathrm{NE}^{4}$ and $A \mathrm{NEZ}{ }^{1}$ seemed to indicate an initial reproductive phase. BENAVIDES \& KUHN (cited by GROGL \& KUHN ${ }^{6}$ ) have found that there is a possibility that $T$. rangeli has an intracellular stage in mammals.

In the subgenus Herpetosoma, forms in division in tissues and visceral capillaries have been reported for $T$. evotomys, $T$. nabiasi, $T$. microti, T. zapi, and T. xeri (HOARE ${ }^{8}$; MOLYNEUX ${ }^{12}$; MARINKELLE \& ABDALLAA ${ }^{10}$ ).

We have found, in experimentally infected suckling white mice, numerous intracellular amastigotes and trypomastigotes of $\mathbf{T}$. rangeli in pseudocysts in the heart, liver, and spleen. In all these organs the morphology and placement of the nests in tissues, as well as of the parasites in the pseudocysts, were similar to those of $T$. cruzi, as described by VIANNA is and KOBERLE ${ }^{9}$.

The finding that the multiplication of $\mathbf{x}$. rangeli in the mammalian host is in the amastigote stage and is intracellular, in contrast to the tissue or blood multiplication of the other members of the subgenus Herpetosoma that have been studied (HOARE ${ }^{8}$ ) suggests study of $\mathbf{T}$. rangeli from a taxonomic point of view, possibly leading to a redefinition of the subgenus.

\section{RESUMEN}

Trypanosoma (Herpetosoma) rangeli Tejera, 1920: Hallazgo de estadios amastigotes con reproduccion intracelular en ratones albinos

El método, sitio y estadio de multiplicación de Trypanosoma (Herpetosoma) rangeli Tejera,
1920 no había sido determinado hasta ahora. Nosotros hemos observado numerosos nidos o pseudoquistes intracelulares que contienen amastigotes $\mathrm{y}$ tripomastigotes de este parásito en el corazón, hígado y bazo de ratones albinos machos de $5,0 \mathrm{~g}$ de peso (cepa NMRI) inoculados por vía i.p. con $9,0 \times 10^{4}$ metatripomastigotes $/ g$ de repique de 12 días en medio LIT, cepa "Perro-82". En el pico de la parasitemia $\left(1,9 \times 10^{6}\right.$ tripomastigotes $/ \mathrm{ml}$ de sangre, 3 dias post-inoculación) fueron retirados varios órganos para seccionar y teñir con hematoxilina-eosina. El corazón fue el órgano mas intensamente parasitado. Los amastigotes son redondeados y ovalados, con núcleo redondeado y kinetoplasto en forma de barra recta o curva; el promedio del diámetro máximo de 50 amas. tigotes medidos fue de $4,2 \mu$. Fue observada fision binaria en el núcleo y kinetoplasto de algunos amastigotes; no fue vista división en los tripomastigotes sanguicolas. Las caracteristicas anteriores, así como tambien la localización de los pseudoquistes en los tejidos, son similares a T. cruzi. La comparación de estos re sultados con los reportados para otros Hexpetosoma sugiere el estudio de la posición taxanómica de $\mathbf{T}$. rangeli.

\section{ACKNOWLEDGEMENTS}

The Authors wish to thank Mr. Ian McLure for technical assistance and the English translation; Mrs. Nuria Tejero for preparing the graph; Mrs. Carmen E. Bermudez for histological preparations; Dr. Cecilia Scorza for fertile discussion; the Consejo de Desarrollo Científico y Humanistico de la Universidad Central de Venezuela (Project No. C 05.4/81) for financial support. Special thanks are due to Dr. Nestor Añez (Universidad de Los Andes, Venezuela) for supplying us with the strain for the parasite.

\section{REFGRENCES}

d. ANEZ, N. - Studies on Trypanosome rangeli Tejera 1920. 1. Deposition migration and growth of $T$. ranged in two mammals. In: PARASITOLOGICAC TOPICS Kansas, Allen Press, 1981. (Spec. Publ. No. 1, Soc Protozool.)

2. BONAY, P.: VIVAS, J. \& URBINA, J. - (Manuscript in preparation), 1885 .

3. D'ALESSANDRO, A. - Blology of Trypanosomm (herpetosoma) rangell Tejera 1920. In: IUUMSDEN, $W$ 
URDANETA-MORaLES, S. \& TEJERO, F. - Trypanosoma (Herpetosoms) rangell TEJeRA, 1920. Intracellular emast1gote stages of reproduction in white mice. Rev. Inst. Med. trop. São Paulo, 28:166-169, 1986.

H. R. \& EVANS, D. A., od. - Biology of the kinetoplastida. New York, Academic Press, 1976. v. 1, p. 328-393.

4. DEane, M. P. - On the life cycle of trypanosomes of the lewist group and their relationships to other mammalian trypanosomes. Rev. Inst. Med. trop. S. Paulo, 11: $34-43,1969$.

5. GREWAL, M. S. - Studies on Trypanosoma rangeli, a South American human trypanosome. Res. Bull. PanJab Univ., 20: 449-486, 1969.

6. GROCL, M. \& KUHN, R. E. - Identification of anti. gens of culture forms of Trypanosoma crual and Try panosoma rangelf recognized by sera from patients with chronic Chagas' disease. J. Paraisit., 70: 822-824, 1984.

7. HERBIG-SANDREUTER, A. - Further studies on Trypanosoma rangeli Tejers, 1920. Acta trop. (Basel), 14: 193-207, 1957.

8. HOARE, C. A. - The trypanosomes of mammals. A zoological monograph. Oxford, Blackwell Scientific Publication, 1972. 749p.

9. KOBERLE, F. - Chagas' disease and Chagas' syndromes: The pathology of American trypanosomiasis. In: DAWES, B., ed. - Advances in parasitology. New York, Academic Press, 1968. v. 6, p. 63-116.

10. MARINKELIE, C. J. \& ABDALLA, R. E. - The multiplication stages of Trypanosoma (Herpetosoma) xeri in the liver of the Sudanese ground squirrel Xerus (Euxeres) erythropus. J. Wildife Dis., 14: 11-14, 1978.

11. MOLYNEUX, D. - Division of the human trypanosome. Trypanosoma (Hexpetosoma) rangeli. Ann. trop. Med. Parasit., 67: 371-372, 1973.
12. MOLYNEUX, D. - Biology of trypanosomes of the subgenus Herpetosoma. In: LUMSDEN, W. H. R. \& EVANS, D. A., ed. - Biology of the kinetoplastida. New York, Academic Press, 1976. v, 1, p. 285-325

13. PIFANO, F. - Nueva tripanosomiasis humana producids por el Typanosoma rangeli, con especial referencia a Venezuela. Arch, venes. Met. trop., 2: 89-120, 1954.

14. PIFANO, F. - EI estado actual de la tripanosomiasis rangeli en Venezuela. Arch. Venez. Med. trop.; 5: 185-192, 1973.

15. TEJERA, E. - Un nouveau flagelle de Rhodnius prolixus. Trypanosoma (ou Crithidia) rangeli n. sp. Buh. Soc. Path. exot., 13: 527-530, 1920.

16. TOBIE, E. J. - Experimental transmission and biological comparison of strains of Trypanosoma rangeli. Exp. Parasit., 11: 1-9, 1961.

17. URDANETA-MORALES, S. \& TEJERO, F. - Trypanosoma (Herpetosoma) rangell Tejera, 1920: Mouse mo del for high, sustained parasitemia. J. Parasit., 71: (in press), 1985.

18. VIANNA, G. - Contribuiçāo para o estudo da anatomia patolojica da Molestia de Carlos Chagas. Mem. Inst. Osw. Cruz, 3: 276-294, 1911.

19. ZRLEDON, R. - Tripanosomíasis rangeli. Rev. Biol. trop. (S. Jose), 2: 231-268, 1954.

Recebido para publicaçäo em 22/7/1985. 